\title{
A new concept for aquaponic systems to improve sustainability, increase productivity, and reduce environmental impacts
}

\author{
Werner Kloas ${ }^{1,3,4, *}$, Roman Groß ${ }^{1}$, Daniela Baganz ${ }^{2}$, Johannes Graupner ${ }^{1}$, \\ Henrik Monsees ${ }^{1}$, Uwe Schmidt ${ }^{4}$, Georg Staaks ${ }^{2}$, Johanna Suhl ${ }^{2,4}$, Martin \\ Tschirner ${ }^{1,4}{ }^{4}$ Bernd Wittstock ${ }^{1}$, Sven Wuertz ${ }^{1}$, Andrea Zikova ${ }^{1}$, Bernhard Rennert ${ }^{1}$ \\ ${ }^{1}$ Department of Ecophysiology and Aquaculture, Leibniz-Institute of Freshwater Ecology and Inland Fisheries, \\ Müggelseedamm 310, 12587 Berlin, Germany \\ ${ }^{2}$ Department of Biology and Ecology of Fishes, Leibniz-Institute of Freshwater Ecology and Inland Fisheries, \\ Müggelseedamm 310, 12587 Berlin, Germany \\ ${ }^{3}$ Present address: Department of Endocrinology, Institute of Biology, Humboldt University, Unter den Linden 6, 10099 Berlin, \\ Germany \\ ${ }^{4}$ Present address: Albrecht Daniel Thaer-Institute of Agricultural and Horticultural Sciences, Department of Crop and \\ Animal Science, Division of Biosystem Engineering, Humboldt University, Invalidenstraße 42, 10115 Berlin, Germany
}

\begin{abstract}
Aquaculture is globally the fastest growing sector of agriculture that needs to be sustainable and must also meet bioeconomic demands. In principle, aquaponics, the combination of aquaculture and horticulture within a single recirculating aquaponic system (SRAPS), provides a sustainable approach; however, it has lower productivity of both fish and plants in comparison to separate recirculating systems. The aim of our new concept for aquaponics is to improve sustainability and productivity concomitant with lowering environmental emissions. The aquaponic system for (nearly) emission free tomato and fish production in greenhouses (ASTAF-PRO) is a new combination of systemic parts, consisting of 2 independent recirculating units: an aquaculture system (RAS) for fish and a hydroponic unit for plants. Both systems are connected by a 1-way valve to deliver fish water containing nutrients into the hydroponic reservoir, where the fish water can be optimized as fertilizer in order to meet specific demands of the plant species. Thus, our double recirculation aquaponic system (DRAPS) can provide optimum conditions for both parts to increase productivity and to prevent any adverse interactions between plant and fish units. Water use is minimized by condensing the plant evapo-transpired water via air conditioning and returning it into the RAS. Testing of the ASTAF-PRO prototype successfully demonstrated the principle using a combination of tilapia and tomato production. Tilapia productivity was similar to single RAS, while tomato production at least indicated the potential for similar efficiency to conventional hydroponics. Thus, ASTAF-PRO improves sustainability and productivity while lowering environmental emissions, and might promote future application of aquaponics for food security.
\end{abstract}

KEY WORDS: Aquaponics concept $\cdot$ Tilapia $\cdot$ Tomato $\cdot$ Sustainability $\cdot$ Productivity $\cdot$ Minimization of emissions $\cdot$ Food security

\section{INTRODUCTION}

The growth of the world's population is expected to nearly stabilize at just above 10 billion people after 2062 (UN 2014b) and poses challenges concerning

${ }^{*}$ Corresponding author: werner.kloas@igb-berlin.de security of water, food, and energy for humans in the $21^{\text {st }}$ century. Water is the primary resource for life and is the main input to produce agricultural goods in the field and throughout the entire agro-food supply chain. Energy is required to distribute water, pro-

(C) The authors 2015. Open Access under Creative Commons by Attribution Licence. Use, distribution and reproduction are unrestricted. Authors and original publication must be credited. 
duce food, and to process and transport agricultural goods. Agriculture is the largest global user of water, accounting for $70 \%$ of total withdrawal, and the food production and supply chain consumes $\sim 30 \%$ of energy produced globally (UN 2014a). Thus, water, food, and energy are inextricably linked by interacting with each other, and the water-food-energy nexus must be managed in a sustainable way concomitant with the protection of the environment to also maintain biodiversity.

In order to fulfill global needs for valuable animal protein, aquaculture is by far the fastest-growing sector of agriculture to supply humans with fish (FAO 2014). However, not all aquaculture production technologies for fishes are environmentally sustainable and meet bioeconomical demands. Thus there is an urgent need to integrate aquaculture within the water-food-energy nexus into agricultural production systems using value-added chains concomitant with lowering adverse environmental impacts.

In the early 1970s, recirculating aquaculture systems (RAS) were designed to rear fish in land-based tanks with continuous recycling of water (Bohl 1977, Krüner \& Rosenthal 1983) to optimize water use. The major challenge in RAS is the fact that the final product of protein metabolism of fish is excreted as ammonia, which is highly toxic for fish. Therefore, aquaculture engineering developed biofilters for nitrification, converting ammonia by aerobic bacteria via nitrite into less toxic nitrate (Collins et al. 1975). However, nitrate accumulation can also have adverse effects on fish (Freitag et al. 2015), and thus, recently, modern RAS focusing solely on fish production often include an anaerobic denitrification unit (Martins et al. 2010), making the whole system more complex. The more conventional approach is to replace daily process water with fresh water in the range of 6 to $12 \%$ of the rearing volume to maintain good water quality with regard to nitrogen load. Such fish wastewater contains relatively high concentrations of nitrate and phosphorus, which are essential macronutrients for plants. Discarding nutrient-rich fish wastewater adversely affects the environment by causing eutrophication of aquatic ecosystems, or it can increase production costs if it has to be passed into sewage treatment plants. Therefore, several attempts have been undertaken in the past to make use of fish wastewater for plant nutrition by aquaponic systems, a portmanteau for combining freshwater aquaculture with soilless plant production in hydroponic systems (Sneed et al. 1975, Naegel 1977). In principle, the general system design as reviewed by Rakocy et al. (2006) is a single recirculating aquaponic system (SRAPS) where, in comparison to conventional RAS that only focuses on fish production, the biofilter unit for nitrification is largely reduced or completely reset by a large hydroponic unit of great variety (Rakocy 2012, Love et al. 2014) and can be located in- or outdoors. A conventional aquaponic system is a SRAPS with interconnected aquaculture and hydroponic parts providing value-added chains with regard to the double use of water by fish and plants. Nutrients from fish waste recycled for plant growth in the hydroponic system reduce negative environmental impacts. These designed SRAPS have been a great step forward towards sustainability in regard to resource efficiency for water and nutrients. During the passage through the hydroponic unit, most excreted toxic ammonia is converted by bacteria into much less toxic nitrate that is then consumed by plants, and the cleared water is directly launched further to the fish tanks.

However, although the established SRAPS have already greatly improved the sustainability of aquaculture, there are some principle facts and disadvantages which do not allow optimum production for both fish and plants in such systems. First, all fish and aerobic bacteria used for nitrification, e.g. the genera Nitrobacter and Nitrosomonas, have a pH optimum of $\sim 7$ to 9 , whereas most hydroponic plant species usually prefer pH levels between 5.8 and 6.2 (Rakocy et al. 2006). Therefore, if the $\mathrm{pH}$ is optimal for fish, plant growth is inhibited and vice versa, thereby reducing the productivity of at least 1 of the components of the system. Due to the single circuit, the nutrient concentrations are relatively low in the effluent of fish tanks and cannot accumulate as in a RAS because they are always consistently removed by the hydroponic part. This is why SRAPS are somewhat restricted to produce plants with lower nutrient requirements, such as lettuces and herbs. In order to raise the amount of nitrogen waste, fish are usually reared at relatively high stocking densities and supplied with high amounts of feed, leading to an unusually high feed conversion ratio (FCR: kg feed / kg biomass gained) as exemplified for tilapia, for which ratios between 1.7 and 1.8 have been reported (Rakocy et al. 2006). Typically, tilapia should have an FCR of $\sim 1.0$, which is also the basis for economical production, since fish diets are the biggest cost factor in intense aquaculture (FAO 2006). Finally, due to the large size of the hydroponic units and the evaporation of water by the plants, water use per day is assumed to be relatively high, especially in outdoor systems. 
To overcome the disadvantages mentioned above for SRAPS, we developed a new and unique concept for aquaponic systems to improve sustainability, increase productivity, and reduce environmental emissions. Within the framework of the project 'aquaponic system for (nearly) emission free tomato and fish production in greenhouses' (ASTAF-PRO), a prototype was designed and generated in order to test the practical proof of principle for this new approach.

\section{MATERIALS AND METHODS}

\section{System design}

In contrast to SRAPS, the basic design of ASTAFPRO (Fig. 1) consists of a double recirculation aquaponic system (DRAPS) consisting of a RAS for the fish-rearing unit and a recirculating hydroponic unit for plant growth, both being coupled in 2 ways. From the aquaculture to the hydroponic unit, the water flow is unidirectionally connected by a 1-way valve, and thus in the ASTAF-PRO system the water does not directly go back into the fish tanks. The whole system is set up in a greenhouse, including air-conditioning that allows water which has been evapo-transpired via plants and water surfaces to be regained by condensation in cooling traps. The regained process water is then fed back into the aquaculture com- ponent. Returning this evaporated water into the RAS minimizes the overall freshwater consumption of the aquaponic system and is an innovative feature of the ASTAF-PRO system.

The electrical power for the ASTAF-PRO system was generated by alternative energy using photovoltaics. For the first practical rearing trial in 2009, we selected a combination of Nile tilapia Oreochromis niloticus and tomatoes Solanum lycopersicum.

The greenhouse used is a conventional type made of polycarbonate twin-wall sheet, with floor space of $17.35 \times 9.60 \mathrm{~m}$ and a total height of $4.75 \mathrm{~m}$. The RAS for fish rearing consists of 9 square fish tanks, of which 7 tanks have a rearing volume of $0.53 \mathrm{~m}^{3}$ each and the other 2 tanks are $2.1 \mathrm{~m}^{3}$ each, resulting in a total rearing volume of $7.91 \mathrm{~m}^{3}$. One additional $0.53 \mathrm{~m}^{3}$ tank is used for lime milk addition to stabilize the $\mathrm{pH}$ at $\sim 7$ for the RAS. The effluent of fish tanks is cleared of solid particles by a lamellae clarifier with a volume of $2.0 \mathrm{~m}^{3}$, and the solid-free water is launched into the sump of the biological filter unit $\left(2 \times 1.3 \times 0.6 \mathrm{~m}\right.$, volume: $\left.1.56 \mathrm{~m}^{3}\right)$ set up as a trickling filter. Furthermore, an additional $1 \mathrm{~m}^{3}$ water is in the water pipes and trickling filter during the run of the RAS, for a total water volume of the whole RAS of $13 \mathrm{~m}^{3}$. In the sump, 1 pump (capacity $10 \mathrm{~m}^{3} \mathrm{~h}^{-1}$ ) lifts the water on top of the trickling filter to a rotating irrigation sprinkler, and another pump (capacity $30 \mathrm{~m}^{3} \mathrm{~h}^{-1}$ ) launches the water into the fish tanks to recirculate the process water in the RAS. In addition,

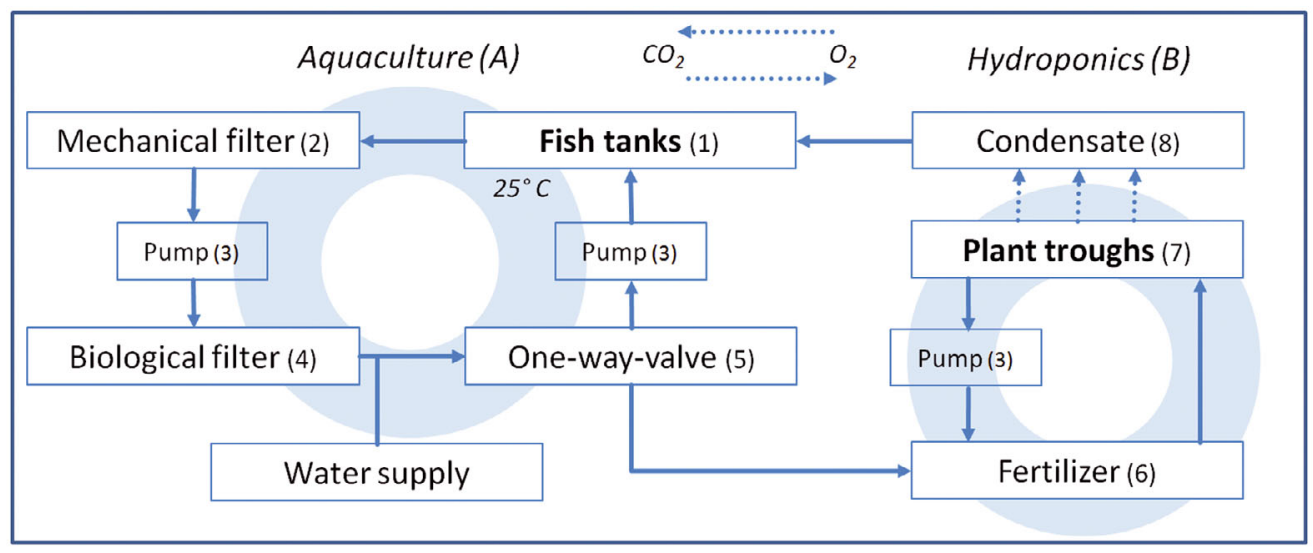

Fig. 1. The aquaponic system for (nearly) emission free tomato and fish production in greenhouses (ASTAF-PRO) consists of 2 independent recirculation systems connected unidirectionally from the fish component to the plant component. (A) The aquaculture unit is in principle a recirculating aquaculture system (RAS), and (B) the plant unit resembles a hydroponic system. The RAS consists of (1) fish-rearing tanks, (2) a lamellae clarifier, (3) a recirculation pump system, and (4) a biofilter (trickling filter) for nitrification. (5) A 1-way valve connects the RAS to the (6) fertilizer reservoir of the separate hydroponic unit, where the fish water can be optimized for specific demands of the plant species and a recirculation pump system provides the flow from the reservoir within the hydroponic unit to feed (7) the plant troughs. The plants take up water and nutrients and vaporize water that is mainly gained via condensation by (8) air-conditioning and then re-fed into the aquaculture unit. In addition to value-added chains for water and nutrients, carbon dioxide is used as a nutrient for plants, which in turn provide oxygen via photosynthesis 
2 heaters, each with a power of $6 \mathrm{~kW}$, are inserted to warm up the water when needed to maintain a constant temperature of $\sim 25^{\circ} \mathrm{C}$. The trickling filter consists of a polyethylene cylinder with a width of $1.45 \mathrm{~m}$ and a total height of $2.70 \mathrm{~m}$, and the filling material has a volume of $\sim 4 \mathrm{~m}^{3}$, for a total surface of $\sim 880 \mathrm{~m}^{2}$. The water passing through the trickling filter for nitrification returns degassed and saturated with oxygen. Water flow is regulated to exchange the volume of fish tanks twice per hour. In addition, all fish tanks are aerated via an air blower to maintain the oxygen supply for the fish.

The hydroponic unit is based on a nutrient film technique (NFT) to supply water and nutrients via a thin film to the roots and consists of 3 parallel aluminum troughs with lengths of 10.73, 12.51, and $12.96 \mathrm{~m}$, respectively, and a profile of $0.3 \times 0.3 \mathrm{~m}$. The troughs are covered by black-and-white foil to prevent light reaching the roots and to inhibit algal growth and evaporation from the water surface. The tomato plants grow soilless on mineral wool cubes placed in the NFT troughs. The fertilizer consists of the clarified fish water from the sump of the trickling filter. It is stored in a reservoir with a volume of $0.8 \mathrm{~m}^{3}$ and is launched via a pump (capacity $9.5 \mathrm{~m}^{3}$ $\mathrm{h}^{-1}$ ) into the catchment tank to be evenly distributed into the hydroponic troughs where the nutrient film follows gravity to recirculate back into the fertilizer reservoir.

The specific difference of the ASTAF-PRO system compared to conventional SRAPS is the fact that with the ASTAF-PRO, both recirculation systems run separately from each other and are only connected via a 1-way-valve between the fish RAS and the hydroponic unit. Thus, the major advantage of this DRAPS with separated aquaculture and hydroponic units is the fact that in both parts, optimum conditions can be set up independently for increasing productivity and to prevent any adverse interactions between plant and fish units. For instance, after delivering fish water to the hydroponic reservoir, there is the potential to optimize the fertilizer (i.e. the fish water) with regard to $\mathrm{pH}$ and macro- as well as micronutrients for the plant species produced. Therefore, in several aquaponic systems, nutrients like $\mathrm{Ca}, \mathrm{K}$, and $\mathrm{Fe}$ are added (Rakocy et al. 2004, 2006).

The greenhouse is set up with automatic shading and an insulating system for the regulation of light and temperature and, in addition, the hydroponic unit is supplemented with 18 sodium discharge lamps (power $600 \mathrm{~W}$ ) to bridge periods of low light exposure. To regain water vaporized mainly by plant transpiration, an air conditioning system with cooling traps is installed. This system consists of 3 ventilation units, each equipped with a cooler, a heater, and a ventilator, 2 heat pumps $(27 \mathrm{~kW})$, and 2 heat exchangers for heating or cooling. The set value for the greenhouse temperature is $23^{\circ} \mathrm{C}$. The water regained by the heat exchanger of the air-conditioning system is collected, measured, and reintroduced into the aquaculture component.

As described above, it is feasible to supplement the fertilizer in the reservoir of the hydroponic unit to optimize nutrient contents. Thus, at the beginning of the practical test, 2 nutrient solutions were dissolved in water, first CalciNit ${ }^{\mathrm{TM}}\left(20 \mathrm{~g} \mathrm{l}^{-1}\right)$ and second

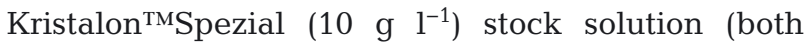
obtained from Yara). CalciNit ${ }^{\mathrm{TM}}$ contains $15.5 \%$ total $\mathrm{N}\left(14.4 \% \quad \mathrm{~N}-\mathrm{NO}_{3}\right.$ and $\left.1.1 \% \quad \mathrm{~N}-\mathrm{NH}_{4}\right)$ and $26.3 \%$ calcium oxide $(\mathrm{CaO})$, while Kristalon ${ }^{\mathrm{TM}}$ Spezial is a nitrogen-phosphorus-potassium fertilizer with $18 \%$ total $\mathrm{N}\left(4.9 \% \mathrm{~N}_{-} \mathrm{NO}_{3}, 3.3 \% \mathrm{~N}-\mathrm{NH}_{4}\right.$, and $9.8 \% \mathrm{~N}-$ $\mathrm{CH}_{4} \mathrm{~N}_{2} \mathrm{O}$ ), $18 \% \mathrm{P}_{2} \mathrm{O}_{5}, 18 \% \mathrm{~K}_{2} \mathrm{O}, 3.0 \% \mathrm{MgO}, 2.0 \% \mathrm{~S}$, and trace elements including $\mathrm{Fe}, \mathrm{Mn}, \mathrm{Zn}, \mathrm{B}, \mathrm{Cu}$, and

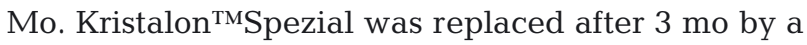
solution mixture of $\mathrm{KHCO}_{3}$ and $\mathrm{K}_{2} \mathrm{HPO}_{4}$.

\section{Evaluation and testing of the ASTAF-PRO prototype}

For the initial set up (3 March 2009) of the testing period, the aquaculture part was stocked with 1280 Nile tilapia with a total weight of $202 \mathrm{~kg}$. Six out of 7 fish tanks with a volume of $0.53 \mathrm{~m}^{3}$ and only 1 of the 2 fish tanks with a volume of $2.1 \mathrm{~m}^{3}$ were stocked, with average weights ranging from 56.0 to $287.7 \mathrm{~g}$ ind. $^{-1}$. Stocking densities were in the range of 32.5 to $65.1 \mathrm{~kg} \mathrm{~m}^{-3}$. Due to growth of fishes the 2 empty fish tanks were stocked until 30 April 2009. The RAS had already been running with fish since 2008 and thus the trickling filter system had already been equipped for the nitrification of nitrogen waste.

Three days later, 116 commercially produced tomato plants (strain 'Admiro') with a height of $\sim 40 \mathrm{~cm}$ were introduced into the hydroponic unit, in Troughs 1,2 , and 3 with 36, 40, and 40 plants, respectively.

The first $4 \mathrm{wk}$ were used to adapt the system for both parts. The lime tank (volume $0.53 \mathrm{~m}^{3}$ ) was supplied each day with $300 \mathrm{~g} \mathrm{CaO}$ and set to an exchange rate of $0.5 \mathrm{~m}^{3} \mathrm{~d}^{-1}$ in order to stabilize the $\mathrm{pH}$ to $\sim 7$.

The test period started on 3 March with fish stocking adapted to fish weight and tank volume, and the whole testing duration with feeding lasted from 6 March to 26 November 2009. Every 28 d, tilapias were sampled to remove individuals grown to $\geq 500 \mathrm{~g}$ and to retain at least $300 \mathrm{~kg}$ total biomass 
in fish of various sizes in respective tanks. Between each sampling, tilapia were fed with commercial pellets ('Aller Performa $1 \mathrm{gr}$ ', Emsland-Aller Aqua, containing 56\% protein, 11\% fat, $15.5 \%$ nitrogen-free extract, $11.2 \%$ ash, $1.6 \%$ phosphate) at an average feeding rate of $1.25 \%$ for $26 \mathrm{~d}$ because the day before and during the sampling, the tilapia were not fed. After sampling, the amount of feed given was adapted for each individual fish tank according to the total weight of the reared fish. The lamellae clarifier was cleaned once per week to remove sludge, and water was collected and measured but was not subsequently used for tomato plants due to space limitations for the hydroponic unit. Harvesting of ripe tomatoes started in May, and nutrient concentrations of $\mathrm{N}-\mathrm{NO}_{3}, \mathrm{~N}-\mathrm{NO}_{2}, \mathrm{~N}-\mathrm{NH}_{4}, \mathrm{P}-\mathrm{PO}_{4}, \mathrm{~K}, \mathrm{SO}_{4}$, $\mathrm{Ca}, \mathrm{Mg}, \mathrm{Fe}, \mathrm{Mo}, \mathrm{Cl}, \mathrm{Na}$, and $\mathrm{Cu}$ were

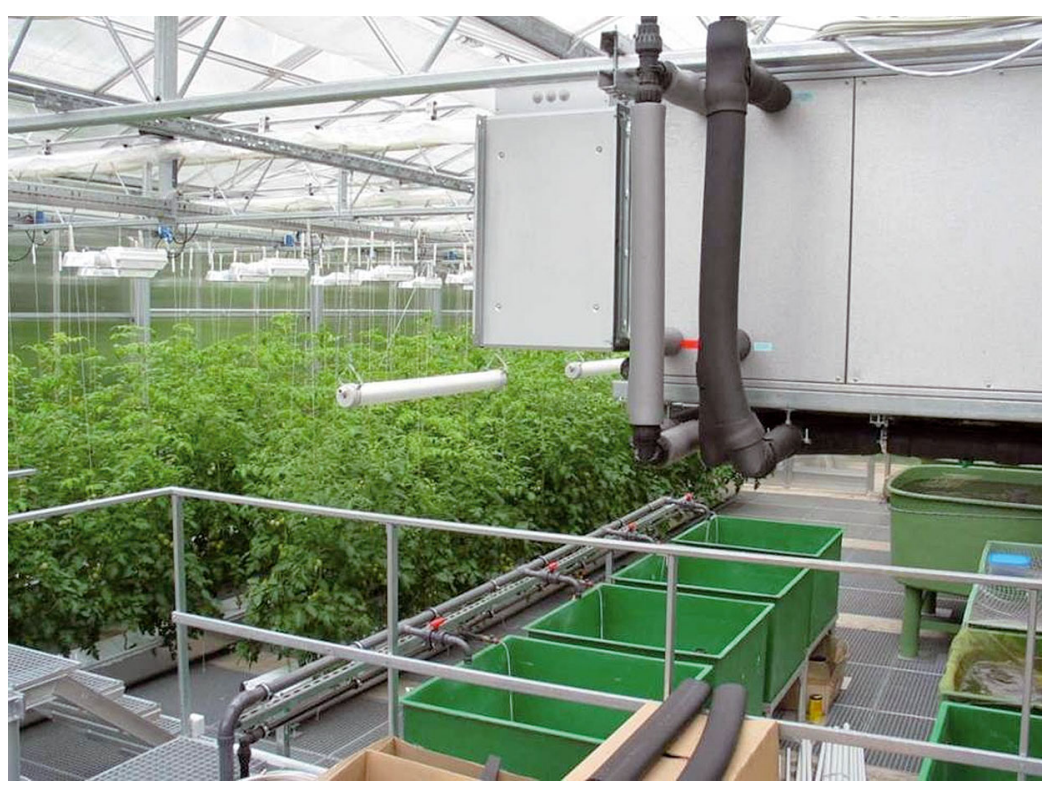

Fig. 2. ASTAF-PRO prototype during the test period in early April 2009, showing aquaculture fish tanks (green boxes) containing tilapia (Oreochromis niloticus) and hydroponic troughs with tomato plants Solanum lycopersicum and the air-conditioning system well as in the hydroponic recirculation system each week in the sump of the trickling filter and in the catch tank of the hydroponic unit. Electrical conductivity and $\mathrm{pH}$ were measured daily.

\section{RESULTS}

The start of the aquaponic trial with ASTAF-PRO was successful for both components of the system, viz. the aquaculture RAS and the plant hydroponics unit (Fig. 2). Unfortunately, on 1 August 2009, a complete power failure for the whole greenhouse occurred and lasted about half a day, resulting in the loss of $>150 \mathrm{~kg}$ of tilapia, especially of the smaller ones. In order to replace the lost tilapia, only larger individuals from the last sampling could be used. This affected the entire feeding trial significantly due to the stressed remaining tilapia and the higher FCR of the introduced larger individuals with weights of $>500 \mathrm{~g}$. For the tomato plants, no obvious adverse impact was noticed. A flow chart illustrating the movement of nutrients in the system is provided in Fig. 3.

\section{RAS}

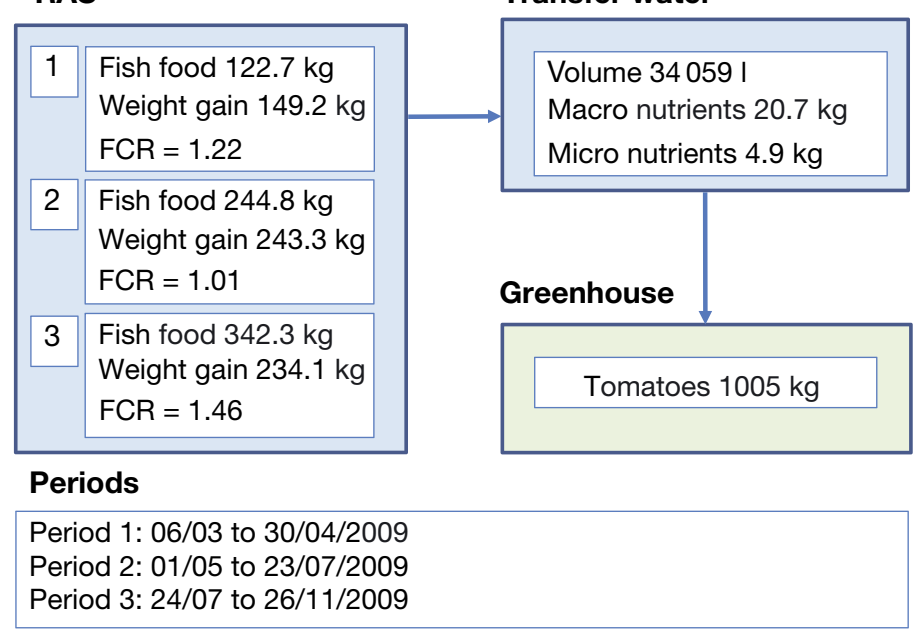

\section{$\%$ of optimal} plant supply

Macronutrients

\begin{tabular}{lr}
\hline $\mathrm{N}-\mathrm{NO}_{3}$ & $128.41 \%$ \\
\hline $\mathrm{N}-\mathrm{NO}_{2}$ & \\
\hline $\mathrm{N}-\mathrm{NH}_{4}$ & $2.71 \%$ \\
\hline $\mathrm{P}^{-\mathrm{PO}_{4}}$ & $17.80 \%$ \\
\hline $\mathrm{K}$ & $17.02 \%$ \\
\hline $\mathrm{SO}_{4}$ & $239.13 \%$ \\
\hline $\mathrm{Ca}$ & $325.00 \%$ \\
\hline $\mathrm{Mg}$ & $678.68 \%$ \\
\hline
\end{tabular}

Micronutrients

\begin{tabular}{lr}
\hline Fe & $3.75 \%$ \\
\hline $\mathrm{Mo}$ & $140.00 \%$ \\
\hline $\mathrm{Cl}$ & - \\
\hline $\mathrm{Na}$ & - \\
\hline $\mathrm{Cu}$ & $60.00 \%$
\end{tabular}

Fig. 3. Nutrient flow through the ASTAF-PRO system (see Fig. 2). The total amounts of nutrients coming from the recirculating aquaculture system (RAS) are given along with the corresponding percentages of optimum fertilizer supply (table to the right). Fish feed weight, fish weight gain and feed conversion ratio $\left(\mathrm{FCR}_{i} \mathrm{~kg}\right.$ feed / $\mathrm{kg}$ biomass gained) are given for each of the 3 periods; volume of transferred water and tomato biomass are total values over the whole testing period 


\section{Tilapia production}

Until the end of April, a total biomass of $>300 \mathrm{~kg}$ was reached in the RAS. During that period, fish were also stocked in parallel into the 2 initially fishfree tanks to maintain mean stocking densities of $\sim 38$ to $45 \mathrm{~kg} \mathrm{~m}^{-3}$ during each sampling period. Over the whole testing period, the weight gain of tilapia was $600.1 \mathrm{~kg}$ using $736.2 \mathrm{~kg}$ feed (Fig. 4). Thus, the overall FCR ( $\mathrm{kg}$ feed / kg biomass gained) over the whole testing period was 1.23 . However, after stocking densities were accomplished for all fish tanks containing in total at least $300 \mathrm{~kg}$ tilapia, during the first period (1 May to 23 July) without disturbance by the electrical failure (1 August 2009), the RAS revealed a gain of tilapia of $243.3 \mathrm{~kg}$ using $244.8 \mathrm{~kg}$ feed, indicating a near optimum FCR of 1.01. After the stress event and the subsequent replacement of dead tilapia by individuals with weights $>500 \mathrm{~g}$, the total gain of tilapia was $234.1 \mathrm{~kg}$ using $342.3 \mathrm{~kg}$ feed, resulting in a higher FCR of 1.46. In order to prevent any further problems concerning continuous energy supply, an emergency power system was implemented in August. of $210.16 \mathrm{~kg}$ that increased in June $(254.41 \mathrm{~kg}$ maximum yield), followed by decreasing yields until November (49.82 kg; Fig. 5). The water use of the tomato plants showed a parallel pattern to the tomato production (Fig. 6). The total harvesting mass of tomatoes was $1005.62 \mathrm{~kg}$, i.e. an average yield of $8.89 \mathrm{~kg}$ tomatoes plant ${ }^{-1}$. It is noteworthy that only a part of the nutrient rich fish water, i.e. $34.06 \mathrm{~m}^{3}$, was used by the hydroponic unit for the tomato plants, resulting in a water consumption of $34 \mathrm{l} \mathrm{kg}^{-1}$ tomatoes. The biomass of tomato plants at the end of the experiment was $551 \mathrm{~kg}$ in total. As expected, the volume of fish water was larger than what could be consumed by the tomato plants in our facility. However, as we could not establish a larger greenhouse due to space limitations, the surplus fish waste water had to be discharged during the weekly cleaning of the clarifier $\left(2 \mathrm{~m}^{3}\right.$, in total $\left.\sim 74 \mathrm{~m}^{3}\right)$. This volume could have been used as additional fertilizer for another 250 tomato plants, which could have resulted in a total yield of $\sim 3000 \mathrm{~kg}$ tomatoes and a total tomato plant biomass of $\sim 1800 \mathrm{~kg}$.

\section{Tomato production}

The tomato plants grew very well, and in all 3 troughs, 1 plant was accidentally lost, resulting in a final total number of 113 flowering tomato plants. Harvesting tomatoes started in May with a total yield

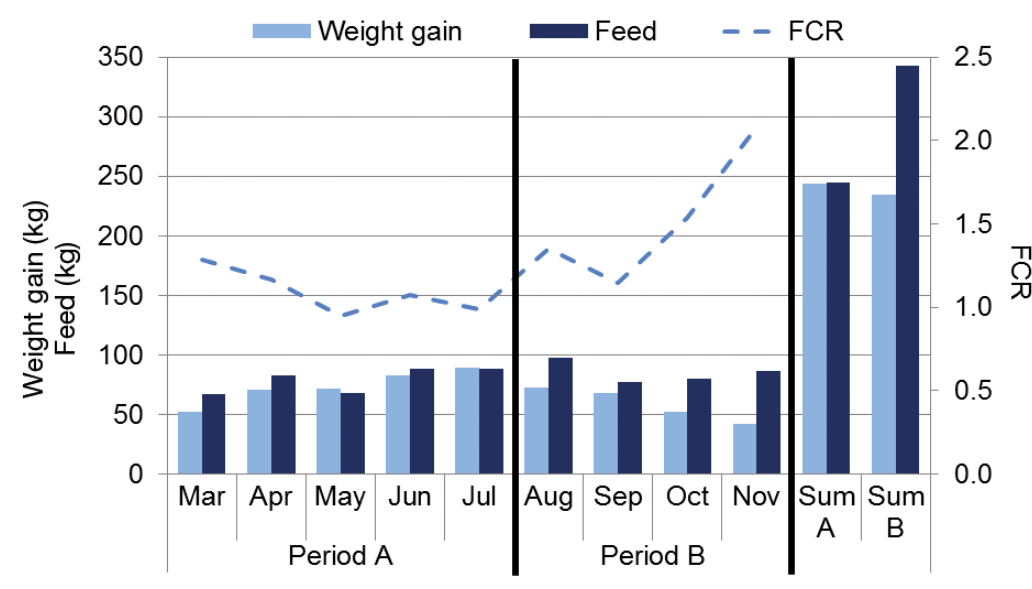

Fig. 4. Weight gain of Nile tilapia Oreochromis niloticus, amount of feed used, and feed conversion ratio (FCR: kg feed / kg gained biomass) during the course of the testing period, separated into periods between 2 sampling events. For comparability of stocking densities, the first part of Period A from March to April until completion of fish stocking (i.e. Period 1 in Fig. 3) has been omitted in Sum A so that it represents the weight gain and feed in fully stocked tanks from May to July. On 1 August, fish were stressed by oxygen depletion following a long-lasting power failure, and $150 \mathrm{~kg}$ of fish died and were replaced by older individuals weighing at least $500 \mathrm{~g}$, which notably affected the FCR

\section{Use of water}

The daily use and introduction of fresh water into the RAS with a total volume of $13 \mathrm{~m}^{3}$ was $3.83 \%$ of the total volume of the RAS. In addition to a small proportion of water lost by evaporation in the RAS and the proportion used to water and fertilize the tomato plants, the largest proportion of introduced fresh water was used in the weekly cleaning of the lamellae clarifier by discharging $2 \mathrm{~m}^{3}$ fish water (see previous section) and sediment into another reservoir and refilling the RAS with $2 \mathrm{~m}^{3}$ of fresh water. The absolute value of added fresh water was $132.4 \mathrm{~m}^{3}$, of which $94.0 \mathrm{~m}^{3}$ were tap water and $38.4 \mathrm{~m}^{3}$ were condensate gained by the climate control unit and added to the RAS. Thus the daily use and net introduction of tap water into the RAS was remarkably low, with only $2.72 \%$. Considering that we could have supplied additional 250 (instead of only 113) tomato plants with fish water in a larger greenhouse resulting in a total of $>360$ tomato plants, the regained evapotranspired water might have increased from $38.4 \mathrm{~m}^{3}$ to $\sim 115 \mathrm{~m}^{3}$. Thus, theoretically, the ratio of added fresh water in terms of tap water:condensed water could 


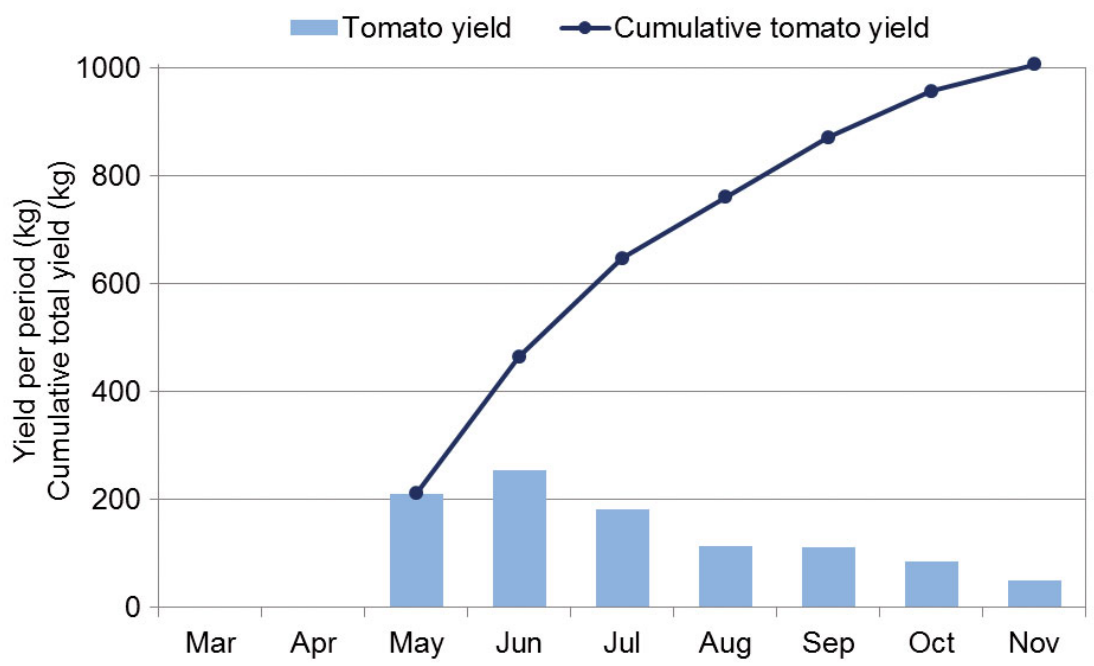

Fig. 5. Tomato Solanum lycopersicum production over the whole testing period. The tomato plants grew normally, and harvesting from a total of 113 plants started in May

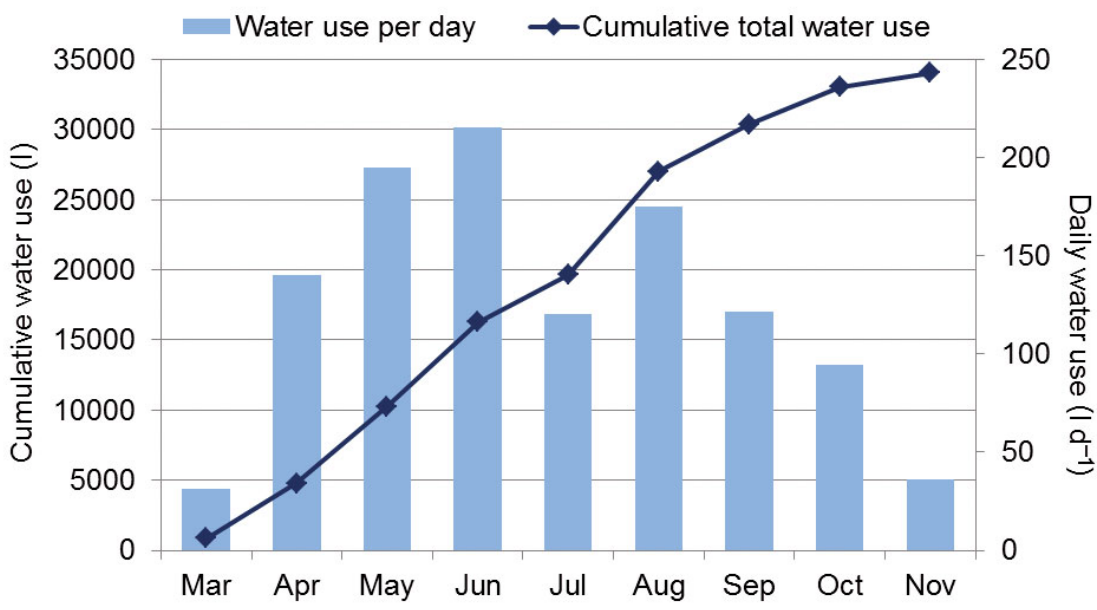

Fig. 6. Use of fish water by tomato plants Solanum lycopersicum during the whole testing period

have changed from 94.0:38.4 $\mathrm{m}^{3}$ to $17.4: 115 \mathrm{~m}^{3}$, meaning that only $17.4 \mathrm{~m}^{3}$ of tap water would have been needed for the whole period because most water would be regained by the climate control unit. That theoretical volume of $17.4 \mathrm{~m}^{3}$ of tap water would result in a daily use and introduction into the RAS of only $0.50 \%$ tap water. During our experimental period, on average $220.6 \mathrm{l}$ of fresh water were used (156.7 l of tap water and $63.9 \mathrm{l}$ of condensed water) to produce $1 \mathrm{~kg}$ of tilapia and $1.67 \mathrm{~kg}$ of tomatoes. As with the $\mathrm{FCR}$, differences between testing periods also occurred in terms of water use. During the first undisturbed period (6 March to 23 July) only $190 \mathrm{l}$ of fresh water (134.9 l tap water and 55.11 condensed water) had to be introduced into the RAS for production of $1 \mathrm{~kg}$ of tilapia. In contrast, because of the stress imposed on the fish by the electrical power failure during the second period (24 July to 26 November), 2671 of fresh water (189.6 l of tap water and $77.4 \mathrm{l}$ of condensed water) were needed to produce $1 \mathrm{~kg}$ of tilapia.

\section{Composition of the fish water used as fertilizer}

The $\mathrm{pH}$ of RAS over the whole testing period was $6.63 \pm 0.38$ (mean $\pm \mathrm{SD}$ ) with a minimum of 5.43 and a maximum of 7.65. Electrical conductivity was $1.65 \pm$ $0.27 \mathrm{mS} \mathrm{cm}^{-1}$, with a minimum of 0.91 and a maximum of $2.25 \mathrm{mS} \mathrm{cm}^{-1}$.

In general, the amounts of the various macro- and micronutrients in the RAS varied during the whole testing period but remained relatively constant in their concentrations, with a tendency to accumulate with decreasing tomato productivity towards the end of the testing period. The mean $( \pm \mathrm{SD})$ concentration of total nutrients was $753.53 \pm 125.30 \mathrm{mg}$ $\mathrm{l}^{-1}$, with the lowest observed value being 526.73 and the highest $983.52 \mathrm{mg} \mathrm{l}^{-1}$. The respective mean values, as well as minimum and maximum values, for $\mathrm{N}-\mathrm{NO}_{3}, \mathrm{~N}-\mathrm{NO}_{2}, \mathrm{~N}-\mathrm{NH}_{4}, \mathrm{P}-\mathrm{PO}_{4}, \mathrm{~K}, \mathrm{SO}_{4}$ $\mathrm{Ca}, \mathrm{Mg}, \mathrm{Fe}, \mathrm{Mo}, \mathrm{Cl}, \mathrm{Na}$, and $\mathrm{Cu}$ are summarized in Fig. 7 and Table 1. During the whole testing period, a total of $34.06 \mathrm{~m}^{3}$ fish water was launched via the 1-way valve from the RAS into the reservoir of the hydroponic unit. Thus a total load of $25.66 \mathrm{~kg}$ nutrients (cf. Fig. 7 for details concerning nutrients) was transferred from the fish RAS into the NFT hydroponic unit for the tomato plants.

\section{Composition of the fertilizer of the hydroponic unit}

The $\mathrm{pH}$ of the hydroponic unit was $6.79 \pm 0.51$ (mean $\pm \mathrm{SD}$ ), with a minimum of 4.30 and a maximum of 7.81. Electrical conductivity was $3.20 \pm$ $0.99 \mathrm{mS} \mathrm{cm} \mathrm{cm}^{-1}$ (minimum and maximum: 0.82 and $5.33 \mathrm{mS} \mathrm{cm}^{-1}$ ), respectively. 


\section{\begin{tabular}{|l|}
$\square$ Nutrient concentration in RAS \\
$\square$ Nutrient concentration in hydroponic unit \\
- Total nutrient load from RAS to hydroponic unit
\end{tabular}}
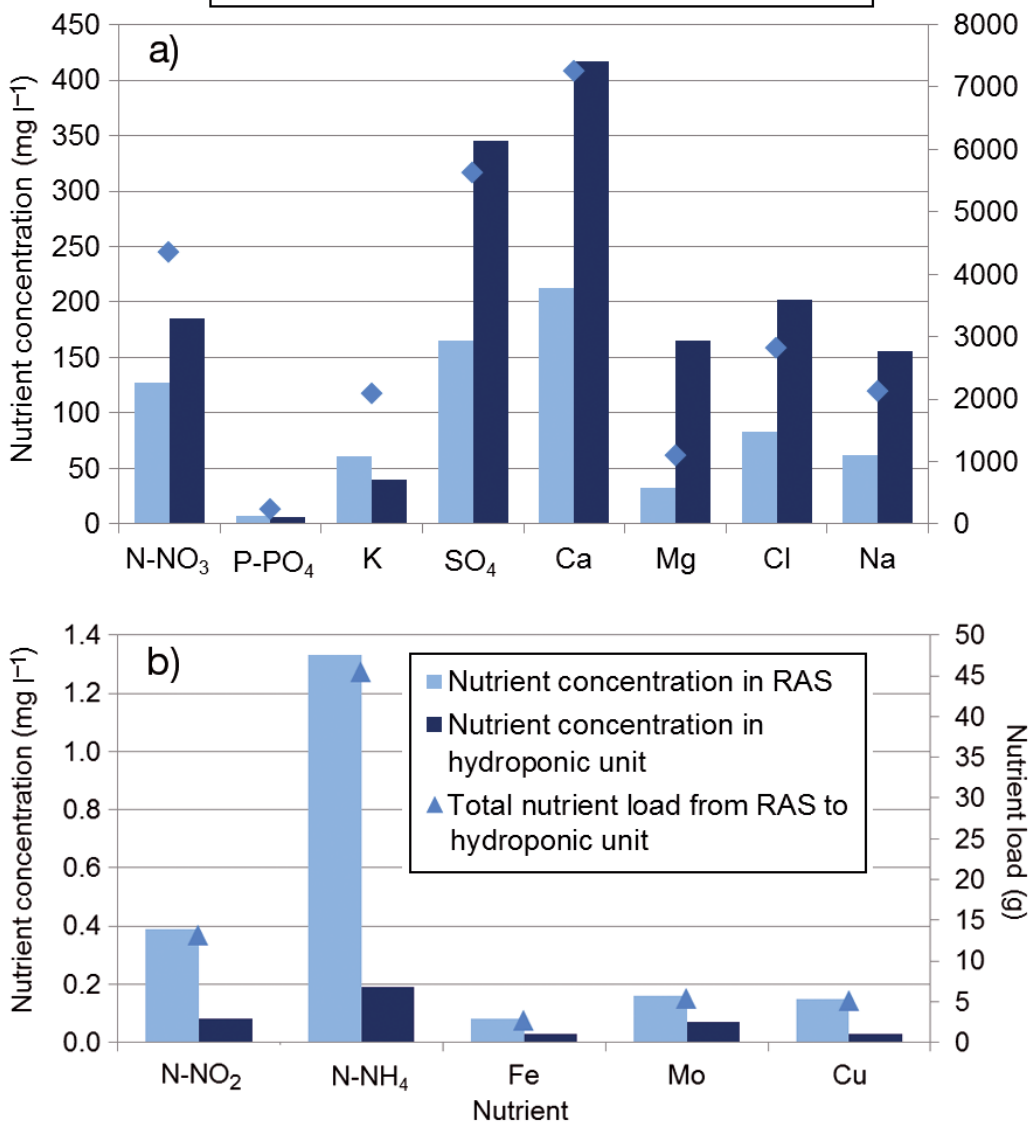

Fig. 7. Means of macro- and micronutrients (cf. Table 1) in the recirculating aquaculture system (RAS) and the hydroponic unit and total load of macroand micronutrients launched from aquaculture RAS into the nutrient film technique (NFT) hydroponic unit of ASTAF-PRO during the testing period from 6 March to 26 November 2009. The total volume of fish water transferred into the hydroponic component was $34.06 \mathrm{~m}^{3}$. Note the different scale between panels $(a, b)$

In addition to the $25.66 \mathrm{~kg}$ nutrients from the fish water (see previous section) to optimize growth conditions, some mineral fertilizer was also introduced into the hydroponic unit (in total: $0.80 \mathrm{~kg}$ Kristalon $^{\mathrm{TM}}$ Spezial, $0.75 \mathrm{~kg}$ CalciNit ${ }^{\mathrm{TM}}, 0.08 \mathrm{~kg} \mathrm{KHCO}_{3}$, and $2.80 \mathrm{~kg} \mathrm{~K} \mathrm{~K}_{2} \mathrm{HPO}_{4}$ ). In general, the nutrients in the hydroponic unit seemed to accumulate during the end of the testing period, which was concomitant with reduced tomato productivity due to decreasing light exposure.

As expected, the mean values of nutrients in the hydroponic unit were higher compared to the fish water of the RAS (cf. Tables $1 \& 2$ ). The mean concentration of total nutrients was $1516.66 \pm 573.40 \mathrm{mg} \mathrm{l}^{-1}$, with lowest and highest observed values of 668.37 and $2709.24 \mathrm{mS} \mathrm{cm}^{-1}$, respectively. The respective mean values including minimum and maximum values for $\mathrm{N}-\mathrm{NO}_{3}, \mathrm{~N}-\mathrm{NO}_{2}, \mathrm{~N}-\mathrm{NH}_{4}, \mathrm{P}-\mathrm{PO}_{4}$, $\mathrm{K}, \mathrm{SO}_{4}, \mathrm{Ca}, \mathrm{Mg}, \mathrm{Fe}, \mathrm{Mo}, \mathrm{Cl}, \mathrm{Na}$, and $\mathrm{Cu}$ are summarized in Tables $1 \& 2$.

Fig. 8 summarizes the means of all nutrients determined over the whole testing period in comparison to the optimum supply for tomato plants according to Lattauschke (2004) and De Kreij et al. (1997). Thus, except for $\mathrm{N}-\mathrm{NO}_{3}, \mathrm{Ca}, \mathrm{Mg}$, $\mathrm{Mo}$, and $\mathrm{SO}_{4}$, all other nutrients were more or less lower than optimal (only 2.71 to $60.0 \%$ of optimum). It is noteworthy that the supply for the most abundant nutrients like $\mathrm{N}-\mathrm{NO}_{3}$ reached $\sim 128.4 \%$ of optimum (and $\sim 239.1 \%$ for $\mathrm{SO}_{4}$ ), but with only $17.0 \%, 17.8 \%$, and $2.71 \%, \mathrm{~K}, \mathrm{PO}_{4}$, and $\mathrm{NH}_{4}$, respectively, were far lower than required for optimum growth.

\section{$\mathrm{CO}_{2}$ balance}

To further sustainability by reduction of emissions with our ASTAF-PRO system, the co-culture of fish and plants within a nearly closed greenhouse in principle allows the $\mathrm{CO}_{2}$ released by the fish to be fixed by the tomato plants. However, due to restrictions in our equipment, we did not measure real $\mathrm{CO}_{2}$ fluxes between fish and plants directly, but we can provide a good conservative estimate of the $\mathrm{CO}_{2}$ balance based on theoretical assumptions of nutrient metabolism.

In total we used $736.2 \mathrm{~kg}$ of diet (Aller Performa $1 \mathrm{gr}$.; $56 \%$ protein, $11 \%$ fat) to gain $600.1 \mathrm{~kg}$ of fish biomass. Neglecting any loss with regard to the digestibility of the diet, the total content for metabolization of the diet fed was $412.3 \mathrm{~kg}$ protein and $81.0 \mathrm{~kg}$ fat. On the other hand, the total gain of tilapia was $600.1 \mathrm{~kg}$, and assuming that tilapia biomass (in terms of whole body content) consists of $15 \%$ protein and $5 \%$ fat, with negligible carbohydrates (AbdelTawwab et al. 2010), this accounts in total for $90.0 \mathrm{~kg}$ protein and $30.0 \mathrm{~kg}$ fat; thus, the net values for potential metabolism in fish and/or for further microbial degradation are $322.3 \mathrm{~kg}$ protein and $51.0 \mathrm{~kg}$ fat. The respiratory quotient $\left(\mathrm{RQ}_{i} \mathrm{CO}_{2}\right.$ liberated divided by $\mathrm{O}_{2}$ consumed) in tilapia is $\sim 1.0$ (Peer \& Kutty 1981), taking into account that protein is the main energy 
Table 1. Mean, minimum, and maximum concentrations $\left(\mathrm{mg} \mathrm{l}^{-1}\right)$ of macro- and micronutrients in the aquaculture recirculation system during the course of the testing period

\begin{tabular}{|c|c|c|}
\hline & Mean & Min. - Max. \\
\hline \multicolumn{3}{|c|}{ Macronutrients } \\
\hline $\mathrm{N}-\mathrm{NO}_{3}$ & 127.69 & 86-168 \\
\hline $\mathrm{N}-\mathrm{NO}_{2}$ & 0.39 & $0.09-0.78$ \\
\hline $\mathrm{N}-\mathrm{NH}_{4}$ & 1.33 & $0.19-5.79$ \\
\hline $\mathrm{P}-\mathrm{PO}_{4}$ & 6.89 & $3.2-16.3$ \\
\hline $\mathrm{K}$ & 61.21 & $32.6-129$ \\
\hline $\mathrm{SO}_{4}$ & 165.37 & $99-238$ \\
\hline $\mathrm{Ca}$ & 212.90 & $142-311$ \\
\hline $\mathrm{Mg}$ & 32.33 & $10-60.8$ \\
\hline Total & 608.11 & $373.08-929.67$ \\
\hline \multicolumn{3}{|c|}{ Micronutrients } \\
\hline $\mathrm{Fe}$ & 0.08 & $0-0.46$ \\
\hline Mo & 0.16 & $0-0.52$ \\
\hline $\mathrm{Cu}$ & 0.15 & $0-2.11$ \\
\hline $\mathrm{Cl}$ & 82.63 & $41-116$ \\
\hline $\mathrm{Na}$ & 62.40 & $36-98$ \\
\hline Total & 145.42 & $77-217.09$ \\
\hline
\end{tabular}

source and in fish is fully degraded to ammonia $\left(\mathrm{NH}_{2} \mathrm{CHCH}_{3} \mathrm{COOH}+3 \mathrm{O}_{2}\right.$ à $\left.3 \mathrm{CO}_{2}+2 \mathrm{H}_{2} \mathrm{O}+\mathrm{NH}_{3}\right)$, whereas fat has a respiratory quotient of $\sim 0.7$. The physical caloric equivalent of protein degraded to $\mathrm{NH}_{3}$ per gram is $22.2 \mathrm{~kJ}$, consumes nearly $1 \mathrm{l}$ of $\mathrm{O}_{2}$, and according to the $\mathrm{RQ}$ of $\sim 1.0$, releases $\sim 11$ of

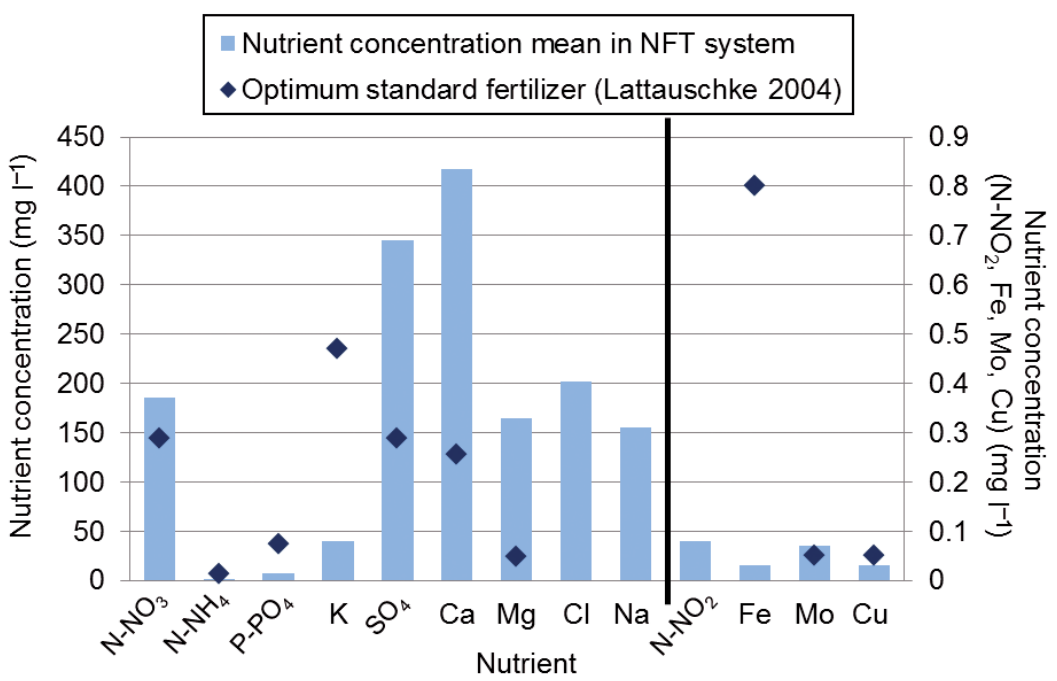

Fig. 8. Optimum standardized fertilizer for tomatoes Solanum lycopersicum according to Lattauschke (2004) (for nitrogen compounds, $\mathrm{P}, \mathrm{K}, \mathrm{SO}_{4}, \mathrm{Ca}, \mathrm{Mg}, \mathrm{Fe}$, $\mathrm{Mo}, \mathrm{Cu}$ ) in comparison to means of macro- and micronutrients in the hydroponic unit (nutrient film technique, NFT) during the course of the experimental testing period revealing the grade of the optimum supply for tomato plants. The critical values for $\mathrm{Na}$ and $\mathrm{Cl}$ according to De Kreij et al. (1997) are 276 and $530 \mathrm{mg} \mathrm{l}^{-1}$, respectively. Left (right) of vertical line: left-hand (right-hand) scale applies
Table 2. Mean, minimum, and and maximum concentrations $\left(\mathrm{mg} \mathrm{l}^{-1}\right)$ of macro- and micronutrients in the hydroponic unit (nutrient film technique, NFT) during the course of the testing period

\begin{tabular}{|lcc|}
\hline & Mean & Min. - Max. \\
\hline Macronutrients $_{N-N O}$ & & \\
$\mathrm{~N}_{3} \mathrm{NO}_{2}$ & 185.17 & $104-316$ \\
$\mathrm{~N}_{4} \mathrm{NH}_{4}$ & 0.08 & $0-0.84$ \\
$\mathrm{P}-\mathrm{PO}_{4}$ & 0.19 & $0-0.99$ \\
$\mathrm{~K}$ & 6.62 & $0-23.9$ \\
$\mathrm{SO}$ & 39.92 & $2.2-170$ \\
$\mathrm{Ca}$ & 344.83 & $167-917$ \\
$\mathrm{Mg}$ & 416.97 & $158-774$ \\
Total & 164.92 & $21-852$ \\
& $\mathbf{1 1 5 8 . 7}$ & $\mathbf{4 5 2 . 2 - 3 0 5 4 . 7 3}$ \\
$\mathrm{Micronutrients}$ & & \\
$\mathrm{Fe}$ & & $0-0.15$ \\
$\mathrm{Mo}$ & 0.03 & $0-0.28$ \\
$\mathrm{Cu}$ & 0.07 & $0-0.33$ \\
$\mathrm{Cl}$ & 0.03 & $41-422$ \\
$\mathrm{Na}$ & 202.43 & $36-237$ \\
Total & 155.40 & $\mathbf{7 7 - 6 5 9 . 7 6}$ \\
\hline
\end{tabular}

$\mathrm{CO}_{2}$. Thus concerning the complete metabolism of $322.3 \mathrm{~kg}$ protein with an RQ of 1.0, the total amount of $\mathrm{CO}_{2}$ that could be released after metabolization is $322300 \mathrm{l}$. The density of $\mathrm{CO}_{2}$ is $1.977 \mathrm{~kg} \mathrm{~m}^{-3}$ (at $1 \mathrm{~atm}$ and $0^{\circ} \mathrm{C}$ ) and thus $3223001\left(322.3 \mathrm{~m}^{3}\right) \mathrm{CO}_{2}$ equals $637.2 \mathrm{~kg} \mathrm{CO}_{2}$. The caloric equivalent per gram of fat is $38.9 \mathrm{~kJ}$, consumes $\sim 2 \mathrm{l}$ of $\mathrm{O}_{2}$, and releases $\sim 1.4 \mathrm{l}$ of $\mathrm{CO}_{2}$. Therefore, the total amount of $\mathrm{CO}_{2}$ that could be liberated by fat metabolization is $714001\left(71.4 \mathrm{~m}^{3}\right)$ of $\mathrm{CO}_{2}$, which equals $141.2 \mathrm{~kg} \mathrm{CO}$. In total, complete metabolization of protein and fat by fish and microbial metabolism could result in a total release of $778.4 \mathrm{~kg} \mathrm{CO}$.

On the other hand, the tomato plants fix $\mathrm{CO}_{2}$ by photosynthesis during plant growth in biomass and, therefore, the plant component of the ASTAF-PRO system is a sink for $\mathrm{CO}_{2}$. Mota et al. (2010) revealed that in $1 \mathrm{~kg}$ biomass of tomato plants, $0.279 \mathrm{~kg}$ $\mathrm{CO}_{2}$ is fixed. We harvested $1005.62 \mathrm{~kg}$ tomatoes, and in addition, we determined that $551 \mathrm{~kg}$ biomass were produced at the end of the plant period, not including the biomass of old leaves removed during the growing period; thus, the total biomass yield was $1556 \mathrm{~kg}$ of tomato plants. How- 
ever, as mentioned above with the discharged cleaning water of $74 \mathrm{~m}^{3}$, an additional 250 tomato plants could have been reared, which would result in a total harvest of 363 tomato plants producing $\sim 3000 \mathrm{~kg}$ of tomatoes and $\sim 1800 \mathrm{~kg}$ of additional biomass. The total tomato plant biomass could therefore have reached $4800 \mathrm{~kg}$. Considering that $0.279 \mathrm{~kg} \mathrm{CO}$ is fixed in $1 \mathrm{~kg}$ tomato plant biomass, the potential total biomass of tomato plants would have fixed $\sim 1339 \mathrm{~kg} \mathrm{CO}$.

Thus, by a very conservative estimation, our experimental trial indicates that if all of the fish water removed from the RAS could be used for the hydroponic unit to grow tomato plants, this would result in a net sink for $\mathrm{CO}_{2}$. Complete metabolization of protein and fat not transferred into fish biomass could lead to a release of $\sim 778.4 \mathrm{~kg} \mathrm{CO}_{2}\left(1.30 \mathrm{~kg} \mathrm{CO}_{2} \mathrm{~kg}^{-1}\right.$ fish biomass), while the complete use of fish water for potential growing of tomato plants would yield a total biomass of $\sim 4800 \mathrm{~kg}$, which could fix $\sim 1339 \mathrm{~kg} \mathrm{CO}_{2}$. Thus in summary, concerning $\mathrm{CO}_{2}$ balance within our ASTAF-PRO system, theoretically no emission of $\mathrm{CO}_{2}$ would arise, and a net sink for $\mathrm{CO}_{2}$ of $\sim 560.6 \mathrm{~kg}$ might even occur.

\section{Patented system}

The innovative principle proposed by the ASTAFPRO system and validated practically herein was patented (Kloas et al. 2008) as a DRAPS characterized by 2 independent recirculation systems for each component, i.e. aquaculture and hydroponic, connected unidirectionally from the fish to the plant unit and gaining vaporized water for the aquaculture unit by condensation via air conditioning, thereby conserving water (Fig. 1). Value-added chains concerning water, nutrients, and carbon dioxide released from fish metabolism supplementing plant growth, which in turn produces oxygen by photosynthesis, foster sustainability of aquaculture RAS by integration with horticulture.

\section{DISCUSSION}

The test evaluation of the ASTAF-PRO system was successful, and despite the electrical power failure in August that adversely impacted at least the tilapia in the RAS, ongoing production of fish and tomatoes was achieved. To prevent similar problems in the future, an emergency power system was implemented within the same month.

\section{Tilapia production}

The total gain in tilapia biomass over the whole feeding trial $(264 \mathrm{~d}$ ) was $600.1 \mathrm{~kg}$, with a productivity rate of about $75.9 \mathrm{~kg}$ tilapia $\mathrm{m}^{-3}$ in a rearing volume of $7.91 \mathrm{~m}^{3}$. However, considering that the fish tanks could all be stocked with a total mass of $300 \mathrm{~kg}$ for the first time at the end of April, the productivity between 1 May and 23 July was considerably higher, with $30.8 \mathrm{~kg} \mathrm{~m}^{-3}$ in $84 \mathrm{~d}$. The adverse effect of the electrical power failure on 1 August that stressed the fish, which was balanced by restocking with individuals already weighing at least $500 \mathrm{~g}$, also became evident as the productivity rate reached only $29.6 \mathrm{~kg}$ $\mathrm{m}^{-3}$ after $124 \mathrm{~d}$. In testing an outdoor approach using SRAPS, Rakocy et al. $(2004,2006)$ revealed a productivity rate for Nile tilapia of $61.5 \mathrm{~kg} \mathrm{~m}^{-3}$ in $168 \mathrm{~d}$ using stocking densities of $\sim 60 \mathrm{~kg} \mathrm{~m}^{-3}$, and $\mathrm{Al}-$ Hafedh et al. (2008) reported a gain of $\sim 43.8 \mathrm{~kg} \mathrm{~m}^{-3}$ within 13 mo. In another SRAPS study in greenhouses, the productivity rate of tilapia was only $15 \mathrm{~kg} \mathrm{~m}^{-3}$ after $105 \mathrm{~d}$ using a very small $\left(0.5 \mathrm{~m}^{3}\right)$ aquaculture unit (McMurtry et al. 1997). Thus, together with the wellestablished SRAPS by Rakocy et al. (2006), our DRAPS ASTAF-PRO system demonstrates the highest productivity rate for tilapia reared in aquaponic systems reported to date. However, the stocking densities used in the recent testing were only between 38 and $45 \mathrm{~kg} \mathrm{~m}^{-3}$ instead of $60 \mathrm{~kg} \mathrm{~m}^{-3}$ used in the SRAPS. In addition, we used a mixed-sex population, whereas Rakocy et al. (2006) reared a faster-growing mono-sex Nile tilapia culture (Popma \& Masser 1999), which is also a parameter to increase productivity.

The FCR (1.01) calculated under undisturbed regular practical conditions (1 May to 23 July) was similar to our conventional RAS unit. After the power failure on 1 August, the ratio increased to 1.46 , demonstrating that stressed fish and the restocked individuals that were already $>500 \mathrm{~g}$ drastically diminished feed conversion; nevertheless, the results demonstrate that in DRAPS with a separated RAS, a nearly optimum FCR for tilapia of $\sim 1.0$ can be obtained, whereas previous aquaponic studies using SRAPS reported FCRs of 1.7 (Rakocy et al. 2004), 1.59 (Watten \& Busch 1984), and 1.4 (Al-Hafedh et al. 2008).

Thus the ASTAF-PRO system demonstrates that with regard to productivity and FCRs, very good yields can be obtained in comparison to separated RAS. However, in the presented testing approach, only very moderate mean stocking densities of tilapia between 38 and $45 \mathrm{~kg} \mathrm{~m}^{-3}$ were used. Thus it is very likely that higher stocking densities of up to 70 to $80 \mathrm{~kg} \mathrm{~m}^{-3}$ (W. Kloas \& B. Rennert unpubl. results for 
our conventional RAS), which still do not affect FCR, can further increase the productivity of tilapia. In addition, the potential use of mono-sex cultures of Nile tilapia as shown by Rakocy et al. (2006) might lead to significant increases in weight gain of tilapia and surpass the yield of established SRAPS.

\section{Tomato production}

The total tomato production of our ASTAF-PRO system with 113 plants resulted in $1005.6 \mathrm{~kg}$ over a growing period of less than 9 mo (6 March to 26 November), for a yield of $8.89 \mathrm{~kg} \mathrm{plant}^{-1}$. In outdoor SRAPS, tomato productivities under different conditions varied greatly, from 0.48 to $3.69 \mathrm{~kg}^{-1 a n t^{-1}}$ (Watten \& Busch 1984) or $4.6 \mathrm{~kg} \mathrm{plant}^{-1}$ (Lewis et al. 1978). In a thorough review, Rakocy et al. (1992) summarized all vegetables grown in aquaponic systems and reported a maximum productivity of 9.07 to $9.98 \mathrm{~kg}_{\text {plant }}{ }^{-1} \mathrm{yr}^{-1}$ for tomato plants, depending on the strain used. McMurtry et al. (1997) obtained values between 2.4 and $5.0 \mathrm{~kg} \mathrm{plant}^{-1}$, depending on the relationship of the volumina between the number of biofilters and the mass of fish reared.

Thus, the tomato production by ASTAF-PRO of $8.89 \mathrm{~kg} \mathrm{plant}^{-1}$ achieved in the present study within less than 9 mo is higher in comparison to previously reported SRAPS (outdoor and indoor) yields, because in conventional greenhouse hydroponics using NFT, the introduction of produced plants usually takes place in January and thus our production period could have been 2 mo longer. In specialized greenhouses for tomato production using comparable NFT systems, a productivity of 15.88 to $20.41 \mathrm{~kg} \mathrm{plant}^{-1}$ has been documented (Anderson 1995). However, in such specialized greenhouses, plant production is increased not only due to optimum fertilizer but also due to optimum artificial illumination which we performed only occasionally (during October and November) and never exceeding the $12 \mathrm{~h}$ day period from 06:00 to $18: 00 \mathrm{~h}$. Artificial illumination maintaining optimum light conditions during the natural day and/or extending the daily light period up to 16 or $18 \mathrm{~h}$ might significantly improve tomato yield $\sim 50 \%$. Thus, the hydroponic unit of ASTAF-PRO has the potential to reach the high performance reported for specialized greenhouses using NFT by increasing the growth period by about 2 mo and by optimizing the illumination conditions. In addition, optimization of the hydroponic fertilizer can be established by increasing stocking densities of fish, leading to higher nutrient concentrations in the RAS, and by adding commercial mineral fertilizer to reach the optimum for otherwise deficient nutrients.
As mentioned in the 'Results' above, we were forced to discharge the fish water during the weekly cleaning of the clarifier due to space limitations. Due to budget restrictions, it was not feasible to enlarge the greenhouse facilities for the hydroponic unit to add another 250 tomato plants to make complete use of the fish water and its nutrients for the hydroponic unit. Considering the potential for a larger hydroponic unit under similar conditions and adapting the corresponding ratio between aquaculture and hydroponics, the total yield of tomatoes should become significantly $>3000 \mathrm{~kg}$.

\section{Use of water}

The freshwater use in the recent ASTAF-PRO performance was $3.83 \% \mathrm{~d}^{-1}$ of the total RAS volume. However, only $2.72 \%$ of the fresh water used was tap water. The rest was introduced as condensed water from the cold traps of the air-conditioning that originated from plant transpiration and water surface evaporation. However, it is hard to compare such values to outdoor aquaponic systems because they gain additional water partially via rain and drainage. Thus, it is more suitable to compare the freshwater use of ASTAF-PRO with indoor RAS in specialized aquaculture units. Optimized RAS systems usually need between 30 and $300 \mathrm{l}$ of fresh water to produce $1 \mathrm{~kg}$ fish biomass (Martins et al. 2010). Even a daily exchange of $10 \%$ is acceptable for practitioners. However, values $<300 \mathrm{l} \mathrm{kg}^{-1}$ fish can only be obtained if the RAS includes an additional denitrification unit, which would, besides the additional introduction of a complex system unit, deteriorate sustainability concerning the further use of fish water as fertilizer for plants. During the testing period of ASTAF-PRO, $132.4 \mathrm{~m}^{3}$ fresh water, $94 \mathrm{~m}^{3}$ tap water, and $38.4 \mathrm{~m}^{3}$ condensed water gained by the climate control unit were added to the RAS. As a result of the water gained by the climate control unit feeding the aquaculture unit, the present study revealed the lowest freshwater use (220.6 1 of fresh water comprising $156.7 \mathrm{l}$ of tap water and $63.9 \mathrm{l}$ of condensed water) per kg fish produced to our knowledge in comparison to established RAS without a denitrification unit. Assuming that an optimized ASTAF-PRO system would have a 3 times larger hydroponic component making use of the complete fish water including the discharged water for clarifier cleaning, it is highly probable that the proportion of water gained by air conditioning would accordingly become greater, which in turn would markedly decrease the need to add fresh water. Theoretically (see 'Results: Use of 
water') in a larger greenhouse, by transferring all fish water, including water from cleaning the clarifier, to supplement 250 additional tomato plants with fish water, the relationship between tap water and condensed water could shift to 29.01 of tap water and 191.61 of condensed water per kg tilapia and would result in a daily introduction rate for tap water of only $0.5 \%$. Depending on the geographic region, additional collection of rain water in the greenhouse area could lead to a complete balance concerning freshwater use, at least in central Europe. However, the energy consumed for condensation, especially during the summer, is high. Thus especially in moderate climate zones with a good water supply, there is a need for an economical evaluation of the optimum regime concerning water condensation via climate control, which is the subject of ongoing research.

\section{Composition of the fish water}

The $\mathrm{pH}$ values of the aquaculture unit were between 5.43 and 7.65 (mean \pm SD: $6.63 \pm 0.38$ ). For tilapia, the optimum $\mathrm{pH}$ range is between 6 and 9 (Popma \& Masser 1999) and thus during the testing period, the tilapia experienced $\mathrm{pH}$ values mostly within their lower $\mathrm{pH}$ optimum. However, nitrification by aerobic bacteria in biofilters requires an optimum $\mathrm{pH}$ between 7 and 8 (Masser et al. 1999) and thus, because of the low buffering capacity of the fresh water used, there was a steady need to stabilize the $\mathrm{pH}$ of the RAS by adding $\mathrm{CaO}$ through the lime tank. At $1.65 \pm 0.27 \mathrm{mS} \mathrm{cm}^{-1}$, the electrical conductivity of the fish water was in an acceptable range for the euryhaline tilapia.

Furthermore, and most importantly for the wellbeing of fish, ammonium, nitrite, and nitrate values within the RAS remained well below any concentration that would adversely affect the fish. In summary, the conditions of the aquaculture part of ASTAFPRO, i.e. the RAS, were always in a very good range for tilapia, and the freshwater use seemed to be advantageous compared to conventional RAS without denitrification.

\section{Composition of the hydroponic fertilizer}

The aquaponic principle, i.e. the transfer of nutrients excreted by fish into plants, was managed successfully in the ASTAF-PRO. Even the productivity of tomato plants was at the high end for aquaponic systems but showed the potential to become even more improved by starting the rearing period earlier and using intensive artificial illumination during sunless periods to reach the same productivity as conventional NFT hydroponic units. In addition, the composition of the fertilizer can be optimized to further increase the tomato yield. Although the concentrations of nutrients could be maintained within the same order of magnitude during the most prominent vegetative period from May to September, the nutrient contents of the fish component were lower due to the fact that tomato plants can take up nutrients selectively, which led to an accumulation of some nutrients in the solution $\left(\mathrm{N}, \mathrm{SO}_{4}, \mathrm{Ca}, \mathrm{Mg}, \mathrm{Cl}, \mathrm{Na}\right.$; Fig. 7). Directly related to the nutrient concentrations is the electrical conductivity, which had a mean of $3.20 \mathrm{mS} \mathrm{cm}^{-1}$, indicating a very good value for hydroponic tomato growth. Electrical conductivity in hydroponic systems used to grow tomatoes in NFT has been reported to be optimal at $3.7 \mathrm{mS} \mathrm{cm}^{-1}$, with a range from 2.5 to $5.5 \mathrm{mS} \mathrm{cm}^{-1}$ (De Kreij et al. 1997). Another experiment reported an optimum of $2.5 \mathrm{mS}$ $\mathrm{cm}^{-1}$ (Sonneveld \& Voogt 1990). Lattauschke (2004) suggested an electrical conductivity of 2.5 to $5.0 \mathrm{mS}$ $\mathrm{cm}^{-1}$ in the root zone of tomatoes growing in rock wool. Thus the electrical conductivity was always near optimum conditions in our study.

The mean $\mathrm{pH}$ during the testing period was 6.79, which is slightly above optimum levels according to the hydroponics literature, where optimum limits have been reported to be between 5.0 and 6.0 (De Kreij et al. 1997), 5.2 and 6.2 (Lattauschke 2004), and 5.5 and 6.5 (Hochmuth 2013). Thus, stabilizing the $\mathrm{pH}$ between 6 and 7 occurred after half of the testing period but should be improved for future experiments. Fig. 8 revealed another more complex pattern regarding which nutrients should be supplemented to optimize the fertilizer (Lattauschke 2004) derived from the aquaculture component. Therefore, nutrient composition of the NFT component documented here is clearly a topic for further optimization of tomato production by adjusting the aquaculture unit to get more of the deficient nutrients or by adding additional nutrients such as $\mathrm{NO}_{3}, \mathrm{NH}_{4}, \mathrm{PO}_{4}, \mathrm{~K}, \mathrm{SO}_{4}, \mathrm{Fe}$, and $\mathrm{Cu}$ in a complementary way. The concentrations of $\mathrm{Cl}$ and Na were below adverse levels (De Kreij et al. 1997), but future adaptations must ensure that these ions do not rise beyond optimum concentrations (Fig. 8).

\section{$\mathrm{CO}_{2}$ balance}

One of the prominent emissions of animal production sites is the release of $\mathrm{CO}_{2}$ caused by the metabo- 
lism of animals, which contributes markedly to the greenhouse gas impact. Unlike birds and mammals, fish do not have to waste energy for body temperature regulation because of their physiological nature as poikilotherms, which is a reason why the production of fish biomass releases relatively low amounts of $\mathrm{CO}_{2}$ by metabolism compared to homoeothermic animals. However, aquaculture fish production sites do release $\mathrm{CO}_{2}$ and thus, in order to foster sustainability by reducing emissions with our ASTAF-PRO system, the co-culture of fish and plants within a nearly closed greenhouse in principle allows the $\mathrm{CO}_{2}$ released by the fish to be fixed by the tomato plants. The conservative estimation for $\mathrm{CO}_{2}$ fluxes within our aquaponics facility reveals an overall theoretical total $\mathrm{CO}_{2}$ release of $778.4 \mathrm{~kg}$ by fish and further microbial metabolization of the feed used and not integrated into harvested fish. On the other hand, the total assumed tomato plant biomass can fix $1339 \mathrm{~kg}$ $\mathrm{CO}_{2}$, meaning that the $\mathrm{CO}_{2}$ balance for ASTAF-PRO reveals a potential net sink for $560.6 \mathrm{~kg} \mathrm{CO} \mathrm{CO}_{2}$ in ASTAF-PRO DRAPS, thereby fostering sustainability. The plant biomass not used for consumption can be further processed for use in biogas plants.

\section{CONCLUSIONS}

In summary, the proof of principle by practical testing of the prototype ASTAF-PRO revealed that such an innovative DRAPS might provide the potential to significantly increase not only the sustainability of aquaculture but also the productivities of both components, viz. aquaculture represented by a RAS and the hydroponic unit using NFT. The innovation is due to a new combination of systemic parts, whereby instead of SRAPS there is a DRAPS composed of 2 independent recirculating units, i.e. the aquaculture RAS rearing fish and the hydroponic unit producing tomatoes. Both systems are connected unidirectionally by a 1-way valve to launch nutrient-containing fish water into the hydroponic reservoir for optimization. Furthermore, the air-conditioning of the greenhouse recycles the transpired water from plants and water evaporation of both systems by condensation via a heat exchanger. The system allows integration of value-added chains for water, nutrients, and metabolized carbon dioxide in a sustainable way and for optimum productivities of both fish and vegetables. Under these conditions it is possible that with $1 \mathrm{~kg}$ feed, $200 \mathrm{l}$ of fresh water (minimizing the proportion of tap water use by condensation of evapo-transpired water), and a small amount of mineral fertilizer, $1 \mathrm{~kg}$ tilapia and $5 \mathrm{~kg}$ tomatoes can be produced in a sustainable way, since the power is supplied by alternative energy and the ASTAF-PRO might even provide a net sink for $\mathrm{CO}_{2}$. Thus a new concept for aquaponic systems has been implemented and validated to improve sustainability, increase productivity, and reduce environmental impacts. In the future, this innovative DRAPS will allow to optimize each part, the RAS and the hydroponic unit, independently. For example, it seems worthwhile to test other promising fish species for their adaptability to the RAS aquaculture part, and for the hydroponic plant part, in addition to using other plant species, to integrate more recent technical developments such as trickling irrigation systems. Recently, the optimization and implementation of the ASTAF-PRO system has been the focus of the ongoing EU-project 'INAPRO - Innovative model \& demonstration based water management for resource efficiency in integrated multitrophic agriculture and aquaculture systems' (www. inapro-project.eu/) to develop further improvements concerning practicability and efficiency for a yeararound production, especially of plants, to facilitate commercial applications.

Acknowledgements. We gratefully acknowledge funding support from the Federal Ministry of Education and Research, Germany (BMBF), via grants 01SF0719, 033L059, and 03IO1304 and from the European Commission via INAPRO (grant agreement number 619137). We also thank Ingo Cuppok, Matthias Kunow, and Jessica Andrä for excellent technical support.

\section{LITERATURE CITED}

Abdel-Tawwab M, Ahmad MH, Khattab YA, Shalaby AM (2010) Effect of dietary protein level, initial body weight, and their interaction on the growth, feed utilization, and physiological alterations of Nile tilapia, Oreochromis niloticus (L.). Aquaculture 298:267-274

Al-Hafedh YS, Alam A, Beltagi MS (2008) Food production and water conservation in a recirculating aquaponic system in Saudi Arabia at different ratios of fish feed to plants. J World Aquacult Soc 39:510-520

Anderson B (1995) Greenhouse tomato production practices. Available at www.uky.edu/Ag/CDBREC/anderson/gh_ tom.htm (accessed 10 March 2015)

Bohl M (1977) Some initial aquaculture experiments in recirculating water systems. Aquaculture 11:323-328

Collins M, Gratzek J, Shotts E Jr, Dawe D, Campbell LM, Senn D (1975) Nitrification in an aquatic recirculating system. J Fish Res Board Can 32:2025-2031

De Kreij C, Voogt W, Van den Bos A, Baas R (1997) Voedingsoplossingen voor de teelt van tomaat in gesloten teeltsystemen. Proefstation voor Bloemisterij en Glasgroente, Naaldwijk

FAO (Food and Agriculture Organization of the United 
Nations) (2006) State of world aquaculture 2006. Fish Tech Pap 500. FAO, Rome

FAO (2014) The state of world fisheries and aquaculture. FAO, Rome

Freitag AR, Thayer LR, Leonetti C, Stapleton HM, Hamlin HJ (2015) Effects of elevated nitrate on endocrine function in Atlantic salmon, Salmo salar. Aquaculture 436: 8-12

Hochmuth G (2013) Fertilizer management for greenhouse vegetables. Florida greenhouse vegetable production handbook, Vol 3. Publication no. HS787. IFAS Extension, University of Florida, Gainesville, FL

Kloas W, Rennert B, Van Ballegooy C, Drews M (2008) Aquaponic system for vegetable and fish production. US Patent and Trademark Office Publication no. US20110131880 A1. Available at www.google.com/ patents/US20110131880 (accessed on 10 March 2015)

Krüner G, Rosenthal H (1983) Efficiency of nitrification in trickling filters using different substrates. Aquacult Eng 2:49-67

Lattauschke G (2004) Gewächshaustomaten: Hinweise zum umweltgerechten Anbau - Managementunterlage. Book 1. Sächsische Landesanstalt für Landwirtschaft, Fachbereich Gartenbau, Pillnitz

Lewis WM, Yopp JH, Schramm HL Jr, Brandenburg AM (1978) Use of hydroponics to maintain quality of recirculated water in a fish culture system. Trans Am Fish Soc 107:92-99

Love DC, Fry JP, Genello L, Hill ES, Frederick JA, Li X, Semmens K (2014) An international survey of aquaponics practitioners. PLoS ONE 9:e102662

Martins C, Eding E, Verdegem M, Heinsbroek L and others (2010) New developments in recirculating aquaculture systems in Europe: a perspective on environmental sustainability. Aquacult Eng 43:83-93

Masser MP, Rakocy J, Losordo TM (1999) Recirculating aquaculture tank production systems: management of recirculating systems. Publication no. 452. Southern Regional Aquaculture Center, Stoneville, MS

McMurtry M, Sanders D, Cure J, Hodson R, Haning B, St Amand E (1997) Efficiency of water use of an integrated fish/vegetable co-culture system. J World Aquacult Soc 28:420-428

Mota C, Alcaraz-López C, Iglesias M, Martínez-Ballesta M, Carvajal M (2010) Investigation into $\mathrm{CO}_{2}$ absorption of the most representative agricultural crops of the region of Murcia. Available at http://www.lessco2.es/pdfs/

Editorial responsibility: Alejandro Buschmann,

Puerto Montt, Chile noticias/ponencia_cisc_ingles.pdf (accessed 10 March 2015)

Naegel LC (1977) Combined production of fish and plants in recirculating water. Aquaculture 10:17-24

Peer MM, Kutty M (1981) Respiratory quotient and ammonia quotient in Tilapia mossambica (Peters) with special reference to hypoxia and recovery. Hydrobiologia 76:3-9

Popma T, Masser M (1999) Tilapia: life history and biology. Publication no. 283. Southern Regional Aquaculture Center, Stoneville, MS

Rakocy JE (2012) Aquaponics - integrating fish and plant culture. In: Tidwell JH (ed) Aquaculture production systems. Wiley-Blackwell, Oxford, p 344-386

Rakocy JE, Losordo TM, Masser MP (1992) Recirculating aquaculture tank production systems: integrating fish and plant culture. Publication no. 254. Southern Regional Aquaculture Center, Stoneville, MS

Rakocy JE, Bailey DS, Shultz RC, Thoman ES (2004) Update on tilapia and vegetable production in the UVI aquaponic system. In: Bolivar R, Mair G, Fitzsimmons (eds) New Dimensions on farmed tilapia. Proceedings 6th Int Symp on tilapia in aquaculture, September 12-16, 2004, Manila, Philippines, p 679-690

Rakocy JE, Masser MP, Losordo TM (2006) Recirculating aquaculture tank production systems: aquaponics - integrating fish and plant culture. Publication no. 454. Southern Regional Aquaculture Center, Stoneville, MS

Sneed K, Allen K, Ellis J (1975) Fish farming and hydroponics. Aquacult Fish Farmer 2:11-18

Sonneveld C, Voogt W (1990) Response of tomatoes (Lycopersicon esculentum) to an unequal distribution of nutrients in the root environment. Plant Soil 124:251-256

UN (United Nations) (2014a) The United Nations World Water Development Report 3-water in a changing world, Book 1. UNESCO Publishing/Earthscan, Paris

UN (2014b) World population prospects: the 2012 revision. Population Division of the Department of Economic and Social Affairs of the United Nations Secretariat, New York, NY

Watten BJ, Busch RL (1984) Tropical production of tilapia (Sarotherodon aurea) and tomatoes (Lycopersicon esculentum) in a small-scale recirculating water system. Aquaculture 41:271-283

Xu J, Mancl KM, Tuovinen OH (2014) Using a hydroponic system with tall fescue to remove nitrogen and phosphorus from renovated turkey processing wastewater. Appl Eng Agric 30:435-441

Submitted: March 11, 2015; Accepted: August 8, 2015 Proofs received from author(s): September 28, 2015 